\title{
CHELATING AGENTS TO SOLUBILIZE HEAVY METALS FROM OXISOLS CONTAMINATED BY THE ADDITION OF ORGANIC AND INORGANIC RESIDUES
}

\author{
Aline Renée Coscione*; Cleide Aparecida de Abreu; Gláucia Cecília Gabrielli dos Santos \\ Instituto Agronômico - Centro de P\&D em Solos e Recursos Ambientais, Av. Barão de Itapura, 1481 - \\ 13020-902 - Campinas, SP - Brasil \\ *Corresponding author <aline@iac.sp.gov.br>
}

ABSTRACT: Phytoremediation is an attractive technique for soils contaminated with heavy metals, especially in conjunction with chelating agents to assist metal phytoextraction. Nevertheless, their studies in Brazil are rare. Thus, the objective of the present work was to evaluate the efficiency of the chelating agents EDDS and EDTA for the solubilization of heavy metals from two Oxisols contaminated by organic sources in Jaguariúna (LVJ) and inorganic sources in Paulínia (LVP), São Paulo State, Southeastern Brazil. First, the soil samples were fractionated and the DTPA method was used to quantify heavy metals available forms. The results indicated that the metals were highly available in the soil fractions and could be solubilized by the chelating agents. The soil was suspended for $24 \mathrm{~h}$ in a chelating agent solution (EDTA or EDDS) at rates of 0, 250, 500 and $750 \mathrm{mg} \mathrm{kg}^{-1}$ of soil. The concentration of solubilized heavy metals was determined in the resulting solution. The extent of metal solubilization varied according to soil type, the chelating agent added and the specific metal. The amount of iron solubilized, as compared to the total iron (LVJ) was $11 \%$ (EDTA) and 19\% (EDDS). EDDS solubilized more Cu than EDTA in both soils but more $\mathrm{Ni}$ in LVJ, while EDTA solubilized more $\mathrm{Zn}$ in both soils but more $\mathrm{Cd}$ in LVP. Both EDTA and EDDS may be useful for phytoextraction from soils, although the iron content is an important factor regarding the phytoextraction of heavy metals with chelating agents in Oxisols.

Key words: soil pollution, chelating agents, tropical soils, fractionation

\section{USO DE QUELANTES NA SOLUBILIZAÇÃO DE METAIS PESADOS DE LATOSSOLOS CONTAMINADOS PELA ADIÇÃO DE RESÍDUOS ORGÂNICO E INORGÂNICO}

\begin{abstract}
RESUMO: A fitoextração tem sido uma opção atrativa para remediar solos contaminados com metais pesados, principalmente quando associada à aplicação de quelantes ao solo, embora no Brasil seus estudos sejam muito incipientes. Portanto, o objetivo deste trabalho foi avaliar a eficiência dos quelantes EDTA e EDDS na solubilização de metais pesados em Latossolos contaminados por $\mathrm{Cu}, \mathrm{Zn}, \mathrm{Cd}$ e $\mathrm{Ni}$, cujas fontes de contaminação foram: orgânica em Jaguariúna (LVJ) e inorgânica em Paulínia (LVP). Antes da solubilização dos metais com os quelantes as amostras de solo foram submetidas ao fracionamento seqüencial e à extração dos metais pesados pelo método do DTPA. Ainda, as amostras dos dois solos foram agitadas com as soluções dos quelantes, por $24 \mathrm{~h}$, usando as seguintes doses: $0,250,500$ e $750 \mathrm{mg} \mathrm{kg}^{-1}$ de solo, realizando-se a determinação dos metais pesados no sobrenadante. Tanto a extração com DTPA como o fracionamento seqüencial indicaram que os metais estavam nas frações disponíveis que poderiam ser solubilizados pelos quelantes. As quantidades solubilizadas de $\mathrm{Cu}, \mathrm{Fe}, \mathrm{Zn}$ e Ni variaram em função do tipo de solo, dos quelantes e das doses aplicadas. A solubilização do Fe em relação ao seu teor total no LVJ foi de 11\% (EDTA) e 19\% (EDDS). O EDDS solubilizou mais Cu em ambos os solos e Ni no LVJ, enquanto o EDTA apresentou maior solubilização do Zn também em ambos os solos e do Cd no LVP. Portanto, a utilização de tais complexantes pode ser promissora na fitoextração de metais em solos, mas a avaliação da concentração de Fe no solo torna-se importante quando se utiliza a técnica de fitoextração assistida por quelantes para remediar Latossolos contaminados com metais.

Palavras-chave: poluição do solo, quelantes, solos tropicais, fracionamento
\end{abstract}




\section{INTRODUCTION}

In the state of São Paulo, Brazil, at least 15\% of the land-contaminated sites are due exclusively to heavy metal addition to the soils (Cetesb, 2007). Metals such as $\mathrm{Pb}, \mathrm{Cd}, \mathrm{Ni}, \mathrm{Zn}$ and $\mathrm{Cu}$ are important since high quantities of them can decrease crop production due to the risk of biomagnification and bioaccumulation in the food chain. There is also the risk of underground and superficial water contamination (Schmidt, 2003; Nowack et al., 2006).

Phytoremediation has become an attractive soil remediation solution due to advantages including the conservation of the soil structure and lesser impact than the usual engineering alternatives as well as favorable economic aspects, among others (Raskin \& Ensley, 2000). However, metal absorption by plants is limited by low metal solubility and transportation in to the root system. In such case, the use of complexing agents to assist phytoextraction of metals has been proposed to enhance metal solubility. In spite of that, some major drawbacks exists such as the toxicity to the soil biology, sometimes even for plant species, and the slow rate of degradation, (Egli, 2001).

In the past few years EDDS ([S,S] ethylenediamine disuccinic acid) has received some attention due to its greater rate of degradation and its strong chelating characteristics comparable to EDTA, although its biodegradation rate varies largely depending upon the examined conditions (Evangelou et al., 2007; Schowanek et al., 1997). Several EDDS phytoremediation studies have been conducted mainly with a soil pH close to neutral (Hauser et al., 2005; Meers et al., 2005; Luo et al., 2005). Under those conditions, EDDS has been more effective than EDTA since the Ca competition for the EDDS is lower. On the other hand, there are no studies addressing this issue in oxidic soils, where Fe should be the major com- petitor for the chelating agent (Tandy et al., 2004; Hauser et al., 2005). Thus, the objective of the present work was to evaluate the efficiency of the chelating agents EDDS and EDTA for the solubilization of heavy metals from Oxisols contaminated by organic sources in Jaguariúna (LVJ) and inorganic sources in Paulínia (LVP) located in São Paulo State, Southeast Brazil.

\section{MATERIAL AND METHODS}

Samples of Rhodic Hapludox soils were collected from the $0-0.20 \mathrm{~m}$ depth in two locations: Paulínia (22 $\left.54^{\prime} 20^{\prime}, \mathrm{S} ; 47^{\circ} 3^{\prime} 39^{\prime}, \mathrm{W}\right)$ and Jaguariuna (22 $46^{\prime} 25^{\prime}$ ' S; 47 06'99', W), SP. The samples were air-dried and sieved to $2 \mathrm{~mm}$. The soil from Paulínia (LVP) was sampled in an area were an accidental leaching of micronutrient raw fertilizer's material occurred, approximately 20 years ago. The area is being monitored by the São Paulo State Environmental Agency (Cetesb, 2007). This soil has a loam texture and high concentrations of available $\mathrm{Cu}, \mathrm{Mn}$ and $\mathrm{Zn}$ (Table 1). The soil from Jaguariuna (LVJ) has a clayey texture and high concentrations of $\mathrm{Cu}$ and $\mathrm{Zn}$ (Table 1). It was sampled in an experimental agricultural corn plot that had previously received sewage sludge yearly (from 1999 to 2005). This site received sewage sludge from the Barueri Wastewater Treatment Facility which has a high metal content. The application rate for the sewage sludge was based on the amount of nitrogen being eight times higher than the nitrogen needed for the corn crop, assuming a 30\% nitrogen mineralization rate in the added sewage sludge (Bettiol \& Camargo, 2006).

The total metal content was evaluated using a microwave nitric acid digestion procedure (Table 2) (US-EPA, 2008). In order to access the "pool" of metals, the soil samples were fractionated in four fractions, namely soluble/exchangeable $(\mathrm{S}+\mathrm{E})$, organic

Table 1 - Chemical and physical characterization of the soils tested.

\begin{tabular}{|c|c|c|c|c|c|c|c|c|c|c|c|c|}
\hline \multirow{2}{*}{ Soil } & \multirow{2}{*}{$\mathrm{OM}$} & \multirow{2}{*}{$\underset{\mathrm{CaCl}_{2}}{\mathrm{pH}}$} & \multicolumn{7}{|c|}{ DTPA } & \multicolumn{3}{|c|}{ Granulometric analysis } \\
\hline & & & $\mathrm{Cu}$ & $\mathrm{Fe}$ & $\mathrm{Mn}$ & $\mathrm{Zn}$ & $\mathrm{Cd}$ & $\mathrm{Ni}$ & $\mathrm{Pb}$ & Silt & Clay & Sand \\
\hline & $\mathrm{g} \mathrm{dm}{ }^{-3}$ & & \multicolumn{7}{|c|}{ - } & \multicolumn{3}{|c|}{ - $\mathrm{g} \mathrm{dm}^{-3}-\ldots$} \\
\hline LVP & 37 & 5.7 & 62 & 14 & 60 & 287 & 0.7 & 0.3 & 9.7 & 320 & 250 & 430 \\
\hline LVJ & 47 & 5.6 & 20 & 159 & 6.0 & 70 & 0.3 & 6.0 & 2.0 & 470 & 89 & 441 \\
\hline
\end{tabular}

*Chemical analysis according to Raij et al. (2001); Physical analysis according to Camargo et al. (1989).

Table 2 - Total metal content (SW 846-3051) in the soils tested.

\begin{tabular}{lcccccccc}
\hline Soil & $\mathrm{Ca}$ & $\mathrm{Cu}$ & $\mathrm{Mn}$ & $\mathrm{Zn}$ & $\mathrm{Cd}$ & $\mathrm{Ni}$ & $\mathrm{Pb}$ & $\mathrm{Fe}$ \\
\hline & $-1-10$ & & & \\
LVP & 1800 & 225 & 481 & 646 & 8 & 8 & 50 & 468.4 \\
LVJ & 2633 & 86 & 110 & 210 & 3 & 30 & 23 & 169.7 \\
\hline
\end{tabular}


matter (OM), oxidable/reducible (OX) and residual (RES) (Anhstrom \& Parker, 1999). The soluble/exchangeable fraction was obtained by addition of 0.1 mol L ${ }^{-1} \mathrm{Sr}\left(\mathrm{NO}_{3}\right)_{2}$ solution followed by a $2 \mathrm{~h}$ agitation and 10 min centrifugation at $6,500 \mathrm{~g}$; the organic fraction was extracted with a $5 \% \mathrm{NaOCl}$ solution at $\mathrm{pH}$ 8.5. The tubes were kept in a $90^{\circ} \mathrm{C}$ water bath for 30 min prior to the centrifugation for extraction of the oxidable/reducible fraction using a solution containing ammonium oxalate $0.2 \mathrm{~mol} \mathrm{~L}^{-1}$, ascorbic acid $0.1 \mathrm{~mol}$ $\mathrm{L}^{-1}$ and oxalic acid $0.2 \mathrm{~mol} \mathrm{~L}^{-1}$ with the $\mathrm{pH}$ adjusted to 3.0. For the residual fraction the samples were oven dried and digested with nitric acid in a microwave oven. The fractionation (in duplicate) was repeated for each extraction step, followed by washing with a $\mathrm{NaCl}$ solution and corrected for soil losses.

The laboratory experimental design was completely randomized, in a full factorial scheme of two soils $\times$ two chelating agents $\times$ four rates (including zero), in triplicate. The chelating agents were EDTA (ethylenediamine tetracetic dissodium salt) and EDDS ([S, S] - ethylenediaminedisuccinic trissodium salt), at rates of $0,250,500$ and $750 \mathrm{mg} \mathrm{kg}^{-1}$ of soil. The chelating agent addition rate were (in $\mathrm{mmol} \mathrm{\textrm {kg } ^ { - 1 }}$ of soil): $0,0.7,1.3,2.0$ of EDTA and $0,0.7 ; 1.4$ and 2.1 of EDDS. The $\mathrm{pH}$ of the chelating agents was measured before their addition. For the EDTA solutions the $\mathrm{pH}$ was of $4.0 \pm 0.2$ and for EDDS the $\mathrm{pH}$ was of $7.0 \pm$ 0.2 for all addition rates.

For each experimental parcel (centrifugue tubes) $3.0 \mathrm{~g}$ of soil and $30.0 \mathrm{~mL}$ of a $\mathrm{CaCl}_{2} 10 \mathrm{mmol}$ $\mathrm{L}^{-1}$ solution containing the chelating agent was added. For the zero addition rates no soil was added before the addition of the $\mathrm{CaCl}_{2}$ solution. Following that sequence, the soil was suspended for $24 \mathrm{~h}$ at $300 \mathrm{~g}$ and centrifuged at 3,000 $\mathrm{g}$ for $15 \mathrm{~min}$ (Nascimento, 2006). The upper layer was separated and $\mathrm{Cr}, \mathrm{Mn}, \mathrm{Fe}, \mathrm{Ni}$, $\mathrm{Cu}, \mathrm{Zn}, \mathrm{Cd}$ and $\mathrm{Pb}$ were determined using an axial ICP-AES, Varian Vista MPX.

The data obtained was submitted to the analysis of variance, considering soil, chelating agent, and addition rates as the source of variance.

\section{RESULTS AND DISCUSSION}

A comparison of the metal content of the studied soils with others reported in the literature confirm that they should be considered as contaminated ones (Table 2). Amounts of $\mathrm{Cd}, \mathrm{Cu}$ and $\mathrm{Zn}$ in the LVP and of $\mathrm{Cd}$ and $\mathrm{Zn}$ in LVJ are close to or above of the maximum content commonly found in most soils (KabataPendias \& Pendias, 1992). Also, when one considers the local environmental agency recommended limit (Cetesb, 2001), the LVJ sample should also be con- sidered as a Ni contaminated one. The reference limit for metal concentrations in São Paulo State soils are (in $\mathrm{mg} \mathrm{kg}^{-1}$ ) $\mathrm{Cu}-35$ and $60, \mathrm{Zn}-60$ and $300, \mathrm{Cd}-$ $<0.5$ and $3, \mathrm{Ni}-13$ and 30 .

The DTPA method for quantifying heavy metals in soil samples (Lindsay \& Norvell, 1978) can be helpful in monitoring soil contamination with $\mathrm{Cd}, \mathrm{Cr}$, $\mathrm{Pb}$ and $\mathrm{Ni}$ (Vidal-Vasquez et al., 2005) in addition to the fact that this method is also useful to evaluate micronutrient availability for agricultural purposes (Abreu et al., 2005). Thus, the levels of $\mathrm{Zn}, \mathrm{Cu}$ and $\mathrm{Cd}$, especially those found in LVP (Table 1), should be of substantial concern due to their high availability to plants and the potential for entering the food chain.

The fractionation of heavy metals in soils is a technique extensively used to enable a better understanding of metal binding to the soil solid phase, which ultimately reflects their availability to plants. This method allows one to follow changes in metal content among different soils, according to the used management procedures (Peters, 1999). Usually, there is a general agreement that the metals found in the soluble/ exchangeable fraction and in the organic matter fraction are more readily available for plant uptake, and consequently more susceptible to binding on chelating agents.

In spite of the source of contamination, inorganic (LVP) or organic (LVJ), the fractionation showed that larger amounts of $\mathrm{Cu}$ were found in the organic matter (OM) and reducible/oxidable (OX) fractions; larger amounts of $\mathrm{Zn}$ were found in the soluble/exchangeable $(\mathrm{S}+\mathrm{E}), \mathrm{OM}$ and $\mathrm{OX}$ fractions; and larger amounts of $\mathrm{Cd}$ were found in the $\mathrm{OX}$ fraction (Table 3).

When compared to total metal amounts found in the soil samples (Table 2) it can be noticed that results (Table 3) correspond to $33.5 \%$ of $\mathrm{Cu}, 12.5 \%$ of $\mathrm{Ni}, 60.5 \%$ of $\mathrm{Pb}$ and $71.4 \%$ of $\mathrm{Zn}$ in the more available fractions (S+E and OM) of LVP. For LVJ, in the same fractions, the results indicate $44.3 \%$ of $\mathrm{Cu}$; $42.3 \%$ of $\mathrm{Ni}, 42.0 \%$ of $\mathrm{Pb}$ and $70.6 \%$ of $\mathrm{Zn}$.

The presence of metals on highly available fractions, such as those examined in this study, should be only expected for the LVJ, the soil contaminated by the addition of sewage sludge, since in the area where the LVP was sampled no organic matter was added either from the accidental leaching or from vegetal sources (Table 1). The addition of metals to the soil due to the repetitive application of sewage sludge leads to a contamination with the metals remaining in the most labile fractions of the soil, mainly due to an organic matter introduction to the system (Bettiol \& Camargo, 2006; Galdos et al., 2004). 
Table 3 - Metal fractionation in the LVP and LVJ soils.

\begin{tabular}{|c|c|c|c|c|c|c|}
\hline Metal & $\mathrm{S}+\mathrm{E}$ & $\mathrm{OM}$ & $\mathrm{OX}$ & RES & Total calculated ${ }^{2}$ & $\%$ to total measured ${ }^{3}$ \\
\hline & - n & 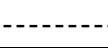 & $-\ldots$ & $--\mathrm{mg}$ & 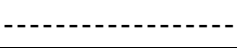 & - \\
\hline & \multicolumn{6}{|c|}{ LVP } \\
\hline $\mathrm{Cd}$ & $<0.1$ & $<0.1$ & 6.0 & 2.5 & 8.4 & 110.8 \\
\hline $\mathrm{Cu}$ & 0.23 & 62.55 & 90.0 & 34.2 & 186.9 & 83.2 \\
\hline $\mathrm{Ni}$ & $<0.1$ & 1.07 & $<0.1$ & 7.1 & 8.2 & 101.0 \\
\hline $\mathrm{Pb}$ & $<0.1$ & 28.56 & 12.0 & 6.7 & 47.2 & 95.1 \\
\hline \multirow[t]{2}{*}{$\mathrm{Zn}$} & 81.4 & 361.50 & 61.0 & 116.2 & 620.1 & 96.0 \\
\hline & \multicolumn{6}{|c|}{ LVJ } \\
\hline $\mathrm{Cd}$ & $<0.1$ & $<0.1$ & 3.9 & $<0.1$ & 3.9 & 125.8 \\
\hline $\mathrm{Cu}$ & 0.2 & 30.2 & 25.3 & 12.9 & 68.6 & 79.6 \\
\hline $\mathrm{Ni}$ & 3.2 & 7.2 & 11.5 & 2.8 & 24.6 & 81.1 \\
\hline $\mathrm{Pb}$ & $<0.1$ & 8.1 & 9.0 & 2.2 & 19.3 & 83.2 \\
\hline $\mathrm{Zn}$ & 32.9 & 104.2 & 41.6 & 15.4 & 194.1 & 92.5 \\
\hline
\end{tabular}

${ }^{1}$ Metal found in pool samples $\mathrm{S}+\mathrm{E}=$ soluble plus exchangeable, $\mathrm{OM}=$ organic matter; $\mathrm{OX}=$ oxidic, RES- residual. ${ }^{2}$ sum of fractions $\mathrm{S}+\mathrm{E}, \mathrm{OM}, \mathrm{OX}$ and RES. ${ }^{3}$ see Table 2

Furthermore, the source of contamination does not appear to have an important role in the metal distribution in the soil's solid phase (Table 3). Among the metals analyzed, substantial $\mathrm{Zn}$ amount was found in the organic matter fraction of both soils. Similar results were reported by Borges \& Coutinho (2004) for a soil treated with sewage sludge, although the fractionation of oxidic soils has also shown that immediately, or longer after the application of the organic matter, a large part of the zinc can be located in the oxidable and residual fractions (Hseu, 2006; Araújo \& Nascimento, 2006). This would be expected by a contamination caused by the introduction of inorganic sources, which result in lower availability for biological agents.

In general, the chelating agents were efficient in the solubilization of heavy metals from the contaminated soil. The extent of metal solubilization varied according to soil characteristics, the added chelating agent and the specific metal considered (Table 4). For both studied soils, for the solubilized amounts of $\mathrm{Cu}, \mathrm{Fe}, \mathrm{Zn}$ and $\mathrm{Ni}$ (only for LVJ) an increase on the extracted amount could be related to the an increase in the applied rates (Figure 1). EDDS solubilized more $\mathrm{Cu}$ than EDTA in both soils. In spite of that, the solubilization of $\mathrm{Fe}$ and $\mathrm{Ni}$ was more affected by the kind of soil (Figure 1), with greater solubilization of $\mathrm{Fe}$ and $\mathrm{Ni}$ in LVJ by EDDS and of $\mathrm{Zn}$ in LVP by EDTA.

In both samples cadmium, even at low concentration, was solubilized only by EDTA. Although Cd is expected to be highly soluble, and thus should be solubilized by both chelating agents, such results can be partly explained by the constant formation of a metal-chelating agent complex. Since the greater the $\log$ of the formation constant, the greater the rate of formation of the chelated form of the metal, Cd-EDTA ( $\log \mathrm{K}$ equals to 16.5$)$ would be preferentially formed to Cd-EDDS ( $\log \mathrm{K}$ equals to 12.7 ) (Tandy et al., 2006). In addition, it should also be noted that $\mathrm{Cd}$ was found in the less available soil fractions (Table 3 ). Therefore, the formation of other complexes with higher concentrated metals, such as those of $\mathrm{Cu}$ and $\mathrm{Zn}$, would be favored, thus reducing further the efficacy of EDDS binding to $\mathrm{Cd}$. Similar results were reported before by Meers et al. (2005) and Luo et al. (2005).

None of the chelating agents tested efficiently solubilized $\mathrm{Pb}$. This suggests that even when assisted with chelating agents the use of phytoextraction to the clean $\mathrm{Pb}$ up from soil may be limited due to its low solubilization. Pereira et al. (2007) evaluated the effect of EDTA on maize grown in a soil containing 2,400 $\mathrm{mg} \mathrm{kg}{ }^{-1}$ of $\mathrm{Pb}$ and observed a transference factor from soil to shoots of 0.52 and 0.57 with and without of $0.5 \mathrm{mg} \mathrm{kg}^{-1}$ of EDTA, respectively. In an experiment with castor bean, sunflower, pepper and tobacco Zeitouni (2003) observed that the removal of $\mathrm{Pb}$ in an Oxisol varied from 0.01 (sunflower) to 0.07 (tobacco) in the absence of EDTA and from 0.02 (sunflower) to 0.38 (tobacco) with the addition of $1 \mathrm{mmol} \mathrm{kg}^{-1}$ of EDTA to the soil.

The solubilization of Fe was important for both the soils and chelating agents studied (Table 4). This can be explained by the greatest metal-chelating agent complex formation constant for EDTA and EDDS with iron (log K Fe-EDTA 25.1 and $\log$ Fe-EDDS 23.7) (Tandy at al., 2004; Tandy et al., 2006). 
Table 4 - Metal solubilized by EDTA and EDDS from contaminated Oxisol, compared to the total metal content (shown in Table 2) ${ }^{1}$.

\begin{tabular}{|c|c|c|c|c|c|}
\hline Chelating agent & $\mathrm{Cd}$ & $\mathrm{Cu}$ & $\mathrm{Fe}$ & $\mathrm{Ni}$ & $\mathrm{Zn}$ \\
\hline $\mathrm{mg} \mathrm{kg}^{-1}$ of soil & \multicolumn{5}{|c|}{ - } \\
\hline EDTA & \multicolumn{5}{|c|}{ LVP } \\
\hline 0 & $<0.6$ & $<0.02$ & $<0.01$ & $<0.6$ & 3.6 \\
\hline 250 & 0.8 & 3.6 & 0.08 & $<0.6$ & 7.85 \\
\hline 500 & 1.3 & 6.7 & 0.16 & $<0.6$ & 11.5 \\
\hline 750 & 2.0 & 9.2 & 0.20 & $<0.6$ & 15.4 \\
\hline \multicolumn{6}{|l|}{ EDDS } \\
\hline 0 & $<0.6$ & $<0.02$ & $<0.01$ & $<0.6$ & 3.6 \\
\hline 250 & $<0.6$ & 16.1 & 0.01 & $<0.6$ & 2.8 \\
\hline 500 & $<0.6$ & 24.7 & 0.31 & $<0.6$ & 6.3 \\
\hline 750 & $<0.6$ & 27.7 & 0.66 & $<0.6$ & 11.4 \\
\hline EDTA & \multicolumn{5}{|c|}{ LVJ } \\
\hline 0 & $<1.7$ & $<0.06$ & 0.2 & 1.0 & 1.8 \\
\hline 250 & 3.0 & 6.9 & 2.1 & 3.1 & 12.8 \\
\hline 500 & 6.3 & 13.1 & 5.4 & 7.1 & 22.0 \\
\hline 750 & 7.7 & 16.8 & 11.0 & 12.1 & 27.3 \\
\hline \multicolumn{6}{|l|}{ EDDS } \\
\hline 0 & $<1.7$ & $<0.06$ & 0.2 & 1.0 & 1.8 \\
\hline 250 & $<1.7$ & 24.0 & 4.5 & 11.5 & 2.2 \\
\hline 500 & $<1.7$ & 30.5 & 12.4 & 18.1 & 3.7 \\
\hline 750 & $<1.7$ & 32.2 & 18.9 & 19.8 & 6.1 \\
\hline
\end{tabular}

${ }^{1}$ Solubilized lead could not be quantified since it was below the instrumental detection limit.
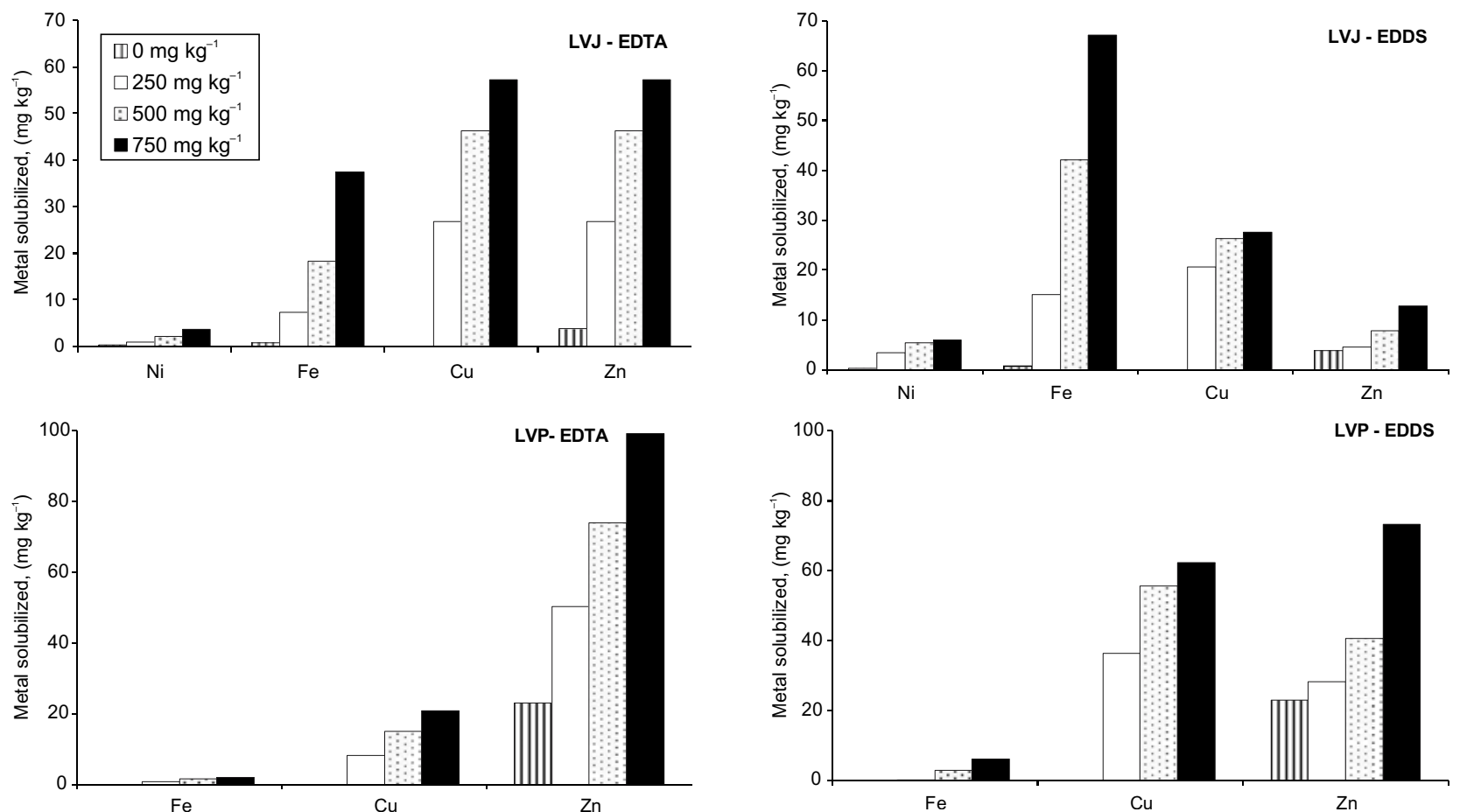

LVP - EDDS

Figure 1 - Metal solubilized from contaminate Oxisols. LVP - contaminated by inorganic residue addition; LVJ contaminated by organic residue addition.

Sci. Agric. (Piracicaba, Braz.), v.66, n.1, p.64-70, January/February 2009 
In addition, although LVJ has a lower total iron content (Table2) much more iron was solubilized from LVJ. Concentrations were 37.5 and $64.2 \mathrm{mg} \mathrm{kg}^{-1}$ for EDTA and EDDS, which correspond to $33.6 \%$ and $54.8 \%$ of the added chelants, respectively. For LVP, the amounts were 1.9 and $6.2 \mathrm{mg} \mathrm{kg}^{-1}$, which correspond to $1.7 \%$ and $5.3 \%$ of the added chelants, respectively. This could be attributed to a large amount of soluble Fe in LVJ, as determined by DTPA (Table 1). Pereira et al. (2007) also reported a high competition of Fe with $\mathrm{Pb}$ by EDTA in phytoextraction studies with maize, more than $90 \%$ of the $\mathrm{Fe}$ in the soil solution was complexed to EDTA applied from 0 to $2400 \mathrm{mg} \mathrm{kg}^{-1}$ of $\mathrm{Pb}$ to the Oxisol. Working with heavy metals column extraction from soils and using EDDS, Hauser et al. (2005), reported that the longer the extraction time the greater the amount of iron leaching. According to the authors, this was due to the formation of Fe(III)EDDS trough slow dissolution of iron oxides. Such studies suggest that the amount of chelating agent to add for assisted phytoextraction from Oxisols should be greater than that needed for the extraction of heavy metal contaminants due to the competition with iron.

$\mathrm{Ni}$ was solubilized only from LVJ, probably due to its greater concentration in LVJ as compared to LVP. For LVP the solubilization of $\mathrm{Ni}$ was quite low for both chelating agents. This may be due to its low concentration in the soil and its presence in soil fractions with low availability (Tables 2 and 3 ) on the examined conditions. For $\mathrm{Ni}$ found in LVJ, EDTA solubilized $12.1 \%$ compared to $19.8 \%$ of EDDS. Thus, for Ni EDDS was a better solubilizing agent than EDTA.

The larger solubilization of $\mathrm{Cu}$ and $\mathrm{Zn}$ in the two soils, as tested with both chelating agents, can be attributed to factors such as their high concentration in the soils, their presence in more labile soil fractions, as indicated either by the DTPA method (Table 2) or the fractionation (Table 3), and the high formation constants of their metal-chelating agent complexes (log k Cu-EDTA 18.8 and $\log \mathrm{k}$ Zn-EDTA 16.5; $\log \mathrm{k}$ Cu-EDDS 20.5 and $\log \mathrm{k}$ Zn-EDDS 15.3) (Tandy et al., 2004; Tandy et al., 2006).

At the greatest rates of EDTA used the $\mathrm{Cu}$ extracted was $9.2 \%$ for LVP and $16.8 \%$ for LVJ; while for EDDS the $\mathrm{Cu}$ extracted was $27.7 \%$ and $32.2 \%$ (Table 4). EDDS was more efficient than EDTA for $\mathrm{Cu}$ solubilization from soil for all the rates tested (Figure 1). This behavior is in agreement with the results obtained by Luo et al. (2005) for artificially multi metal contaminated soils, using an equimolar concentration of chelating agents and metals, for soils with a $\mathrm{pH}$ close to neutral. On the other hand, the largest
Zn solubilization was observed with EDTA, solubilizing $15.4 \%$ for LVP and $27.3 \%$ for LVJ; compared to $11.4 \%$ and $6.1 \%$ with EDDS (Table 4 ). EDTA was superior to EDDS for both soils since for all rates tested it was different from the results reported by Luo et al. (2005) but in agreement with those found by Meers et al. (2005). They examined a dredged sediment derived from surface soil collected at a disposal site in Belgium, with a $\mathrm{pH}$ close to neutral and a high content of organic matter. According to Meers et al. (2005), EDDS promoted a larger mobilization of $\mathrm{Cu}$ and $\mathrm{Ni}$ than EDTA, while for $\mathrm{Zn}$ the effects were comparable for the two chelating agents.

The increase of metal found in the extracts was not in the same order of magnitude for LVP and LVJ. For LVP the following order of increasing solubilization with EDTA and EDDS was found: $\mathrm{Zn}>\mathrm{Cu}$ $>$ Fe with either EDTA as EDDS. On the other hand, for LVJ the solubilization was: $\mathrm{Zn}>\mathrm{Fe}>\mathrm{Cu}$ by EDTA and $\mathrm{Fe}>\mathrm{Cu}>\mathrm{Zn}$ by EDDS. The explanation of these observations is not as trivial as it might seem since the solubilization order suggested by the metal-chelanting agent complex formation constants should be $\mathrm{Fe}>\mathrm{Cu}>\mathrm{Zn}$. Thus, the three factors pointed above should be taken into account to explain this.

Several factors should be considered when comparing chelating agents for heavy metal decontamination of soils (Tandy et al, 2004). Among them, they recommend that the chelating agent/heavy metal ratios should always be larger than one. However, for phytoremediation procedures extensive use of such high concentrations of the chelating agents can damage the plants and produce heavy metal leaching and thus should be carefully done. The major disadvantage of using smaller quantities of chelating agents is the competition with other metals found in soil, which are sometimes in much larger concentrations than the metal contaminants addressed.

\section{CONCLUSIONS}

In general, both EDTA and EDDS were efficient for the solubilization of heavy metals $(\mathrm{Cu}, \mathrm{Ni}, \mathrm{Zn}$ and $\mathrm{Cd}$ ) from cultivated Oxisols contaminated by the addition of organic and inorganic residues. The use of both EDTA and EDDS can de considered promising for phytoextraction procedures.

The evaluation of iron content in soil samples is an important factor to be considered on laboratory procedures for the phytoextraction of heavy metals with chelating agents in Oxisols. 


\section{ACKNOWLEDGEMENTS}

This research was supported by the International Foundation for Science, Stockholm, Sweden, and the Organization for the Prohibition of Chemical Weapons, The Hague, The Netherlands through a grant to Dr. A.R. Coscione (C/4027-1; 2006). The authors are also grateful to Dr. William E. Artz for editing the manuscript.

\section{REFERENCES}

ABREU, C.A.; RAIJ, B. van; ABREU, M.F.; GONZALEZ, A.P. Routine testing to monitor heavy metals and boron. Scientia Agricola, v.62, p.564-571, 2005.

ANHSTROM, Z.S.; PARKER, D.R. Development and assessment of a sequential extraction procedure for the fractionation of cadmium. Soil Science Society of America Journal, v.63, p.1650-1658, 1999.

ARAÚJO, J.C.T.; NASCIMENTO, C.W.A. Zinc fractionation and availability by different extractants in sewage-sludge amended soils. Revista Brasileira de Ciência do Solo, v.29, p.977985, 2005

BETTIOL, W.; CAMARGO, O. Lodo de esgoto: impacto ambiental do uso agrícola. Jaguarúna: Embrapa Meio Ambiente, 2006. $349 \mathrm{p}$.

BORGES, M.R.; COUTINHO, E.L.M. Heavy metals in sol after sewage sludge application. I. Fractionation. Revista Brasileira de Ciência do Solo, v.28, p.543-555, 2004.

CAMARGO, O.A.; MONIZ, A.C.; JORGE, J.A.; VALADARES, J.M.A.S. Métodos de análise química, mineralógica e física de solos do Instituto Agronômico de Campinas. Campinas: Instituto Agronômico, 1989. 94p. (Boletim Técnico, 106).

COMPANHIA DE TECNOLOGIA DE SANEAMENTO AMBIENTAL - CETESB. Relação de áreas contaminadas no Estado de São Paulo. São Paulo: Cetesb, 2007. Available at: http://www.cetesb.sp.gov.br/Solo/areas_contaminadas/ relacao_areas.asp. Accessed 4 May 2008.

COMPANHIA DE TECNOLOGIA DE SANEAMENTO AMBIENTAL - CETESB. Relatório de estabelecimento de valores orientadores para solos e águas subterrâneas no Estado de São Paulo. São Paulo: Cetesb, 2001. 232p.

EGLI, T. Biodegradation of metal-complexing aminopolycarboxylic acids. Journal of Bioscience and Bioengineering, v.92, p.89-97, 2001.

EVANGELOU, M.W.H.; EBEL, M.; SCHAEFFER, A. Chelate assisted phytoextraction of heavy metals from soil: effect, mechanism, toxicity, and fate of chelating agents. Chemosphere, v.68, p.989-1003, 2007.

GALDOS, M.V.; MARIA, I.C.; CAMARGO, O.A. Soil chemical properties and corn production in a sewage-sludge amended soil. Revista Brasileira de Ciência do Solo, v.28, p.569-577, 2004.

HAUSER, L.; TANDY, S.; SCHULIN, R.; NOWACK, B. Column extraction of heavy metals from soils using the biodegradable chelating agent EDDS. Environmental Science and Technology, v.39, p.6819-6824, 2005

HSEU, Z.Y. Extractability and bioavailability of zinc over time in three tropical soils incubated with biossolids. Chemosphere, v.63, p.762-771, 2006.
KABATA-PENDIAS, A.; PENDIAS. H. Trace elements in soils and plants. 2 ed. Boca Raton: CRC Press, 1992. $315 \mathrm{p}$.

LINDSAY, W.L.; NORVELL, W.A. Development of DTPA soil for zinc, manganese and copper. Soil Science Society of America Journal, v.42, p.421-428, 1978.

LUO, C.; SHEN, Z.; LI, X. Enhanced phytoextraction of $\mathrm{Cu}, \mathrm{Pb}$, $\mathrm{Zn}$, and Cd with EDTA and EDDS. Chemosphere, v.59, p.111,2005 .

NASCIMENTO, C.W.A. . Organic acids effects on desoprtion of heavy metals from a contaminated soil. Scientia Agricola, v.63, p. 276-280, 2006.

NOWACK, B.; SCHULIN, R.; ROBINSON, B.H. Critical assessment of chelant-enhanced metal phytoextraction. Environmental Science and Technology, v.40, p.5525-5532, 2006.

PEREIRA, B.F.F; ANREU, C.A.; ROMEIRO, S.; LAGIA, A.M.M.; PAZ-GONZALEZ, A.P. Pb-phytoextraction by maize in a $\mathrm{Pb}-$ EDTA treated oxisol. Scientia agricola, v.64, p.52-60, 2007.

PETERS, R.W. Chelant extraction of heavy metals from contaminated soils. Journal of Hazardous Materials, v.66, p.151-210, 1999.

RAIJ, B.van; ANDRADE, J.C.; CANTARELLA, H.; QUAGGIO, J.A. Análise química para avaliação da fertilidade de solos tropicais. Campinas: Instituto Agronômico, 2001. 285p.

RASKIN, I.; ENSLEY, B.D. Phytoremediation of toxic metals using plants to clean up the environment. New York: John Wiley, 2000. 365p.

SCHMIDT, U. Enhancing phytoextraction: the effect of chemical soil manipulation on mobility, plant accumulation, and leaching of heavy metals. Journal of Environmental Quality, v.32, p.1939-1954, 2003.

SCHOWANEK, D.; FEIJTEL, T.C.J.; PERKINS, C.M. Biodegradation of $[\mathrm{S}, \mathrm{S}],[\mathrm{R}, \mathrm{R}]$ and mixed stereoisomers of ethylene diaminedisuccinic acid (EDDS), a transition metal chelator, Chemosphere, v.34, p.2375-2391, 1997.

TANDY, S.; AMMANN, A.; SCHULIN, R.; NOWACK, B. Biodegradation and speciation of residual SSethylenediaminedisuccunic acid (EDDS) in soil solution after soil washing. Environmental Pollution, v.142, p.191-199, 2006.

TANDY, S.; BOSSART, K.; MUELLER, R.; RITSCHEL, J.; HAUSER, L.; SCHULIN, R.; NOWACK, B. Extraction of heavy metals from soils using biodegradable chelating agents. Environmental Science and Technology, v.38, p.937-944, 2004.

U.S. ENVIRONMENTAL PROTECTION AGENCY - US-EPA. Test methods for evaluating solid waste, physical/chemical methods. 3 ed. Washington, D.C.: U.S.-EPA, 1995 (EPA publication SW-846). Available at: http://www.epa.gov/SW-846/ sw846.htm. Accessed 4 May 2008.

VIDAL-VÁSQUEZ, E.; CARIDAD-CANCELA, R.; TABOADACASTRO, M.M; PAZ-GONZALEZ, A.; ABREU, C.A. Trace elements extracted by DTPA and Melich-3 from agricultural soils with and without compost additions. Communications in Soil Science and Plant Analysis, v.36, p.717-727, 2005.

ZEITOUNI, C.F. Eficiência de espécies vegetais como fitoextratoras de $\mathrm{Cd}, \mathrm{Pb}, \mathrm{Cu}, \mathrm{Ni}$ e $\mathrm{Zn}$ de um latossolo vermelho amarelodistrófico. Campinas: Instituto Agronômico, 2003. 103p. (Mestrado).

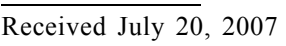

Accepted April 16, 2008 